\section{New Tests for Milk}

The Minister of Health has issued a pamphlet giving directions for carrying out tests to ascertain whether milks entitled to be called 'tuberculin tested', 'accredited' or 'pasteurized' comply with the prescribed standards for the bacterial content of such milks. These standards indicate the cleanliness and keeping qualities of the milk (Bacteriological Tests for Graded Milk (Revised Memorandum 139/Foods. London: H.M. Stationery Office. 3d.). Since June 1, 'tuberculin tested' milk has taken the place of 'certified' and 'Grade A (Tuberculin Tested)' milks ; and 'Accredited Milk' that of 'Grade A' milk. In place of the previous 'plate-count' test, a new test, the methylene blue reduction test, will be applicable to these milks from January 1, and as before, there is a test for the presence of coliform bacilli. Pasteurized milk, whether 'tuberculin tested' milk or not, must comply with a 'plate-count' test. Full directions are given for carrying out these tests, and the pamphlet also explains how samples should be collected.

\section{Marine Boring Animals}

THE damage which may be done to submerged structures of both wood and stone by marine boring organisms is a subject of not only general interest but also of extreme economic importance. In 1919, therefore, the Trustees of the British Museum caused a general account of the habits and life-histories of these organisms to be prepared which, it was hoped, would prove useful to both zoologists and marine engineers. This hope has been amply fulfilled, and the Trustees have now issued a revised edition of the pamphlet incorporating the additions to our knowledge of marine borers which have been made since the publication first appeared (Marine Boring Animals injurious to Submerged Structures. By W. T. Calman. Second edition; revised by G. I. Crawford. British Museum (Natural History), 1936. Is.).

\section{Announcements}

AT the annual meeting of the Royal Agricultural Society of England held on December 9, the Right Hon. Walter Elliot, a former Minister of Agriculture and now Secretary of State for Scotland, was presented with a certificate and badge of honorary life governorship of the Society. In the report presented at the meeting it is stated that the Society's Gold Medal and honorary membership for distinguished services to agriculture has this year been presented to Sir William Cecil Dampier. For some years Sir William has devoted his energies to the organization and development of agricultural research. He was the first secretary of the Agricultural Research Council and steered that body to success through its early difficult years.

AN important experiment in the prevention of malaria, according to the Soviet Union Year Book Press Service, was recently carried out by the Sanitary Department of the Central Asiatic Military District. Before the autumn manceuvres, every soldier was given a dose of acraquinine for several days, and although the manceuvres took place in malaria-infested districts and there were cases of bites by malaria-carrying mosquitoes, not a single case of malaria occurred.

THe Royal Statistical Society offers the Frances Wood Memorial prize, value $£ 30$, for competition in 1937. The prize is offered for the best investigation, on statistical lines, of any problem affecting the economic or social conditions of the people. Further information can be obtained from the honorary secretaries of the Royal Statistical Society, 4 Portugal Street, W.C.2.

Erratum.-In the note on p. 1003 in Nature of Decomber 12, Sir Robert Mond should have been described as president of the French Society of Chemical Industry and not as "past-president".

Applicatrons are invited for the following appointments, on or before the dates mentioned:

Technical officer at the Royal Aircraft Establishment, South Farnborough, Hants-The Chief Superintendent (December 26).

Civilian engineer in the War Department-The Under-Secretary of State (C.5), The War Office, London, S.W.1 (December 31).

Principal of Newport Technical College-The Director of Education, Education Offices, Charles Street, Newport, Mon. (December 31).

Assistant in the Art and Ethnographical Department of the Royal Scottish Museum, EdinburghThe Director (December 31).

Research assistant in botany in University College, Exeter-The Registrar (December 31).

Assistant physicist in the Royal Cancer Hospital (Free), Fulham Road, London, S.W.3 (January 1).

Lecturer in chemistry, botany and zoology in the Technical College, Doncaster-The Secretary (January 2).

Head of the Chemistry Department of the Derby Technical College-Clerk to the Governors, Technical College, Green Lane, Derby (January 9).

Lecturer in native administration in the University of Cape Town-The Secretary, Office of the High Commissioner for the Union of South Africa, South Africa House, Trafalgar Square, London, W.C.2 (January 15).

Research worker in nutrition in the Medical Research Department of the Government of IndiaThe High Commissioner for India, General Department, India House, Aldwych, London, W.C.2 (January 15).

Metallurgist for work on alloy steels and metallurgist for work on non-ferrous alloys in the Mond Nickel Co., Ltd.-The Manager, Research and Development Department, The Mond Nickel Com. pany, Ltd., Thames House, Millbank, London, S.W.1.

Physical chemist to the Printing and Allied Trades Research Association-The Director of Research, 10 Robin Hood Court, London, E.C.4. 